University for Business and Technology in Kosovo

UBT Knowledge Center

Nov 7th, 9:00 AM - 5:00 PM

\title{
Whether Turkey is a really safe haven henceforward for both Turkish and Syrians
}

Meltem Cilek Dirsehan

Marmara University, meltem.dirsehan@marmara.edu.tr

Follow this and additional works at: https://knowledgecenter.ubt-uni.net/conference

Part of the Political Science Commons

\section{Recommended Citation}

Dirsehan, Meltem Cilek, "Whether Turkey is a really safe haven henceforward for both Turkish and Syrians" (2015). UBT International Conference. 11.

https://knowledgecenter.ubt-uni.net/conference/2015/all-events/11

This Event is brought to you for free and open access by the Publication and Journals at UBT Knowledge Center. It has been accepted for inclusion in UBT International Conference by an authorized administrator of UBT Knowledge Center. For more information, please contact knowledge.center@ubt-uni.net. 


\title{
Whether Turkey is a really safe haven henceforward for both Turkish and Syrians
}

\author{
Meltem Çilek Dirsehan \\ Marmara University, Institute of the Middle East Studies, \\ Sociology \& Anthropology of the Middle East Sultanahmet Campus, \\ meltem.dirsehan@marmara.edu.tr
}

\begin{abstract}
Turkey as a safe haven has been welcoming of more than two millions Syrian people without any ethnic or sectarian discrimination for four years. State institutions have spent nearly 6 billion dollars to set a life for asylum seekers in the best refugee camps and without any notable support of United Nations and other external agencies and countries. However, out of the camps, life and safety conditions of especially lower class Syrian people have been getting worse day by day because of security related problems emerging between citizens and Syrian asylum seekers, even in the border cities where local people have more cultural values in common with Syrian community. Actually, \% 54 of Syrian population in Turkey is under 18; publicly in city centres local people have faced with many of these children as beggars, who have been considered as a minor threat for public with their harassing style. By a projection of ten years after, those children who are now canalized in begging groups at the streets, could be exactly predicted as being integrated in criminal gangs; they may easily commit crimes (drug use and sell, pick pocketing, robbing, pandering, harassment, rape, injury, murder etc.) in public, unless they are integrated in society as valuable individuals for social capital of Turkey. An approach for social policy of integration is a proposal for potential conflict resolution in future of Turkey societal security. This study aims at pondering on case of begging Syrian children, who have been far from education for four years and they have been still not enrolled in a formal education. This potential threat for societal security transforms Turkey from haven to hell for both Turkish and Syrians without any institutional enterprises understanding of social capital and integration policy need for security of society.
\end{abstract}

Keywords: asylum seekers and refugees, societal security, social politics, integration

\section{The flow of immigrants to Turkey and legal status of them}

By the end of cold war, Syrian Civil War has been discussed as the worst human tragedies and described as the Turkey as a safe haven which has been welcoming of more than 2.5 millions of Sy rian people without any ethnic or sectarian discrimination for more than four y ears. In the process of Arab Spring related civil unrests and following chaos in the Middle East (as a prevalent Orientalist concept used for South-western Asia), admittedly the deepest security gap has been emerged in Syria and this gap stretching out its borders through neighbour countries toward Europe across Turkey. Not only regime's attacks on civilians, and also internal armed groups, and external rooted fundamental groups collaborating local tribes have been storming the life conditions for civilians. In this paper, it is discussed that indications about extension of war in Syria show us Syrian people with a large population of children (54\%) would have sustain their lives in Turkey. This paper has been planned to make an introduction to security and securitization problem growing together in Turkey around children refugees (officially asylum seekers) from Syria in a method of literature review and fact analysis in the light of the theories on security issues because of asylum seekers and theories on exclusion of invisible others in any society.

Syrian Civil war has transformed into battle war since opposition groups began to be armed against regime forces and then, the external terrorist groups, which are informally backed by global powers, has interrupted Syrian internal power struggle. Two clear security gaps have been emerged in this process for bordering countries; the threats of these terrorist groups' activities stretching over both 
Sy rian and host communities and the flow of migrants from Syria without any discern of criminals or spies of terrorist groups. This paper has been focused on second kind of security issue which needs to be pondered on pauper Syrian children as the most vulnerable group in asylum seekers. Unless the lower class and under class originated children who are exploited by their parents and criminal groups are integrated in social system by social policies, these children will be easily inclined to commit crimes disturbing security of public order. Because of that cross-border criminal activities could be easier by open borders, weak states controls, non-registered immigration flows, criminal gangs have been operated in two sides of border have been organising refugee flow in urban spaces and exploited poor Syrian children and women.[1] Turkish policy makers should take consider a future projection of pauper refugee children and take precautions to risks for societal security related to refugee crisis [2] which is incubated by criminal gangs' manipulation over vulnerable refugee groups. Children as the largest vulnerable group in immigrants suffering in poor conditions in urban have been defined as lost generation by UNHCR reports.[3]

Syrian people have fled not only from violence of regime and militant groups, but also from poverty, unemploy ment, honour and shame codes, destructed patriarchal hierarchy within the kinship. As a bordering country Turkey has faced political, economical and sociological problems because of the dynamics of Syrian war and its gradually complicating frame continues to dislocate Syrians crossing border of Turkey. Although Turkey as an emerging market which has many crisis of adaptation to neoliberal world within its social and cultural indicators [4], Turkish state, NGOs and citizens have welcomed Syrian 'guests' as best as one can do in initial term of flows for the sake of humanity. Pushing effects of civil war and its turning to trench warfare in Syria have made refugee influx continued; and the world's greatest refugee mobility has emerged with many problems of managing high amount of people without documents. Certainly Syrian migrants have some problem with identified as refugee within Turkish migration policies which have no acceptance of people as refugees from non-European countries, decided in The 1951 Refugee Convention Geneva.[5] Although she signed The 1969 Protocol, she has no room for improvements of geographical restrictions for definition of refugee. Turkey defines Syrians under the term temporary protected status which is originated in USA migration policies for people of countries which civil war is going on.[6]

In this legal status frame, Syrians are not regarded as refugees and they are considered as asylum seekers or illegal migrants whether they are registered. UNHCR has been continually updating the population of total recorded Syrian migrants which is declared as 2.181.293 in Turkey. [7] This population is argued as the greatest in the world and the burden of refugee flow is too heavy for Turkey which has 10.529 \$ GDP (2014) [8] relatively when it is compared to advanced economies in EU. However a large amount of unrecorded Syrian migrant population has been resettled out of the 24 camps which are located in 10 different cities of Eastern region of Turkey and municipalities in almost all cities allocate aids for Syrians. Turkish institutions have been mobilised to provide humanitarian aid and relief works, and NGOs and other public groups have organized to help them; totally Turkey have spent more than 7 billion dollars as to explanations of executives to set a life in a system in camps discussed as 'the best camps' ever in worldwide by global media and UNHCR.[9] Without any notable support of UN, external agencies and wealthier countries, these affords of Turkish institutions and people could only contain 261.301 Syrian in camps (equals only \% 12.5) [10] and registered Syrians living out of the camps. Plus to economic burden of refugees, it pressures on local people that Syrians more than the local population (or in a high percentage as to local population) have resettled in some cities along the border such as Kilis. This ty pe of influxes creates a deep shock in local people and threatens the order of society because of that local people have stayed as minority in their own land.[11] However course of events both in Syria's complicated and blurred future, and structural problems, poor conditions and criminal incidents committed by Syrians happening in Turkey have shown that these guests would be neighbours of them and unless they would not be integrated in Turkish system and social capital of Turkey they would threaten host communities security, properties, opportunities.

\section{European indifference on this tragedy of refugee problem}

Turkish definition problem of refugees may be one of the causes in the motivation for the change in Turkey's position in refugee influx. This has been problematic for Europe in the second period of 
2015, when Syrians have been transformed to "boat people" who struggle to illegally emigrate in a second country to get a better standardised European life sty le than they have got in Turkey. Although desperate refugees pay to smugglers and criminal gangs for this dangerous travel, they have been squeezed inhuman plastic boats and sail for death. Refugees have taken as much terrible risks to arrive at shores of EU islands, yet in case of that they have accidentally reached to any territory of EU, surely they have encountered with an ill-treatment and hostility towards them. Global attention on this deep tragedy of Syrians were finally able to be drawn by a little refugee child's (Ailan) photo which is popularised and instrumentalised by and for media. By symbolic power of images coded in this photo influenced public opinion pressuring for opening borders. [12]

Yet, these well-intentioned actions evaporated after people's common sense, which was hurt by Ailan's photo, was satisfied by displays of giving affection, presents, relieves them. Many these kinds of refugee floods from the Middle East have made Europeans standing on tenterhook and EU tries to deal with Turkev to get rid of their refugee coming back to Turkey in return for fiscal aid, visa privileges and new talks on Turkey-EU membershipIn addition to European indifference caused in political disasters, too. NATO underestimated Turkey's suggestion for establishment of No-Fly Zone (NFZ) to protect civilians off more influx. In this process, global organisations turned a deaf ear to mass refugee problem of Turkey until Syrian refugees have swarmed in the portsides of Aegean region to arrive at the EU lands by boats or forced the EU door by walk through the border fences. As for Sy ria , today Russia have burst upon Sy rian case and established NFZ on which NATO had just begun to argue.[13]

\section{Syrians positioning out of the camp conditions in Turkey}

Approximately two million (official data: 1.919.992) Syrians have been scattered around all urban cities and just \% 12.5 of total recorded asylum seekers have been concentrated in secure shelters, with basic necessities and safe water, health and food aids, education and vocational courses, and a system of sustenance opportunities for them to maintain their daily routines in camps. Even this system is not enough, it seems relatively better than scattering around the urban streets' ground and beg for money and harass host community. It is shown in many reports that refugees in camps have not lost their bound with their homeland and expected to return after clashes end. [14] This tendency to expect for return home can be cited as the result of being isolated to be integrated in host community. For children mental health causalities and traumas have no much chance to be healed in isolated camps. [15] Generally, my focus on children in lost generation discourse does not include children of relatively wealthier families. It could be cited that people from different classes and status in Syria have been experienced different faces of being refugee in host community. Some Syrians originated in middle and high class have settled in urban areas, rented or bought flats; many entrepreneurs have invested in Turkey such that it is recorded as $26 \%$ of foreign investments belonging to Syrians in 2014; they have opened their own schools and centres for their children. Wealthy Syrians whether they may not oppose to regime, have crossed the borders because of the damaged market and deteriorated economic conditions for keeping life standards, protecting properties and status they had in Syria. [16] They have transferred their wealth to Turkey so they have been able to keep their position in any society by their class roots. They could never be construed as vulnerable as in a comparison with property less, peasant, working and under class originated refugees especially their children. The largest group in Syrian refugees, majority of children in families who could not achieve to transfer their properties to Turkey, live out of the camps and take part in or witness to the connection with illegal earning mechanisms in Turkey to maintain their families' lives. Lower class originated refugee children out of the camps have faced a deep poverty, exploitation and exclusion due to their tendencies in harassing style and committing crime. Thus, Sy rian people in Turkey as a class in itself is vetted in the diversion of living bad and unhealthy conditions in urban areas, in the publicly shared locations such as parks and gardens, in abandoned and demolished buildings, in ruinous flats, rooms without sanitary living conditions. Many insecure conditions have been set for children, malnutrition, and lack of education, poor health care and emotional distress lead them get into criminal gangs and illegal groups.[17] Conflict potential among Turkish citizens and Syrian people with a projection for these women and children without any formal and civil integration policy have been exploited by local opportunist and they also try to enjoy their victimization by alleging rights to have concession. 
For the deep potential conflicts, resolution and social policy ought to be planned to support refugees whose integration in social sy stem, crucially help them to formulate an identity and self esteem, sociocultural value system, give them reasons to live peacefully and accept them as a part of society.[18] This kind of social policies could be cursed by Foucauldian approach because of control mechanism of the state institutions over bodies; nevertheless without any social and economic capital, poor refugees who need shelter, food, health care, education and employment are vulnerable to be socialized in illegal organisations; this risk for losing this generation in the control of criminal groups alleviate the negative sides of defence for bio-political thoughts for marginalised un-protected communities. [19]

Today these children have been considered a minor threat for public with their harassing style which is taught to them by men who organise their arrival and articulation as beggars to such as metropolis Istanbul. Until this period, both of state institutions and host communities in various cities in Turkey have shown a deep hospitable attitude toward Sy rian people mostly comprised of women and children. However, out of the camps, life and safety conditions of especially for lower class Sy rian people have been getting worse day by day because of security related problems emerging between citizens and Syrians, even in the border cities where local people have more cultural values in common with Syrian community. Because of the lack of resources, unemployment, rising prices and incidents of murders, robbery, and prostitution by Syrians irritate host community against this long-term 'guest'. In Eastern bordering cities, family structure has been influenced by Syrian women cracking by the illegal marriages with Turkish husbands. Also, Syrian men have been considered as quisling traitors and awkward who escape from defending their own country in the eye of public. The psychology of scapegoating which is an easily referred mechanism over migrants [20] have been inevitably engaged by local citizens and rising tension because of the soaring prices managed by opportunist capitalists, damages in family structure by Syrian women in marriage market and also Syrians' attacks and criminal actions happened in Turkey. Burden of many myths about migrants which relates to sale competition, labour market, unemployment of the local citizens, prostitution, should not be generalised for all poor Syrian refugees because of that attitude eradicates all possibilities of integration of them.

\section{Conclusion: importance of integration policies for children}

Generalizing of criminal cases over all Syrian refugees brings many other risks of marginalising them and getting them out of the societal system and makes them whetted against local people in future. By a projection of ten years after, those children who are now partly canalized in beggar groups at the streets, could be exactly predicted as being integrated in criminal social binds at streets; they may easily commit crimes (drug use and sell, pick pocketing, robbing, pandering, harassment, rape, injury, murder etc.) in public, unless they are integrated in society as valuable individuals for social capital of Turkey. Today's beggar children could turn into tomorrow's young marginalised adults who may serve for criminal gangs in this process without an ordinary and safe life and values binding them to the public and legal order. [21] So, exclusion of Syrians with these kinds of emerging problems operates with stereo-typing mechanisms and children of this refugee community lose the ground to stand in hosting society. This kind of stigmatisations make them accepted a spoiled identity and tend to part in criminal groups.[22] This means that excluding and stigmatising Sy rians in Turkish society looks inevitable but integration policies, this discrimination against refugees Syrians take societal security in mess and in future there could be no effective solution except taking these children in the legal system when they are children, by educating them and giving them an identity belonging to whole Turkish society.

\section{References}

1. Makarenko. Tamara. "The crime-terror continuum: tracing the interplay between transnational organised crime and terrorism." Global crime 6.1 (2004): 129-145.; Düvell, Franck. "Human smuggling, border deaths and the migration apparatus." Migration Studies 2.3 (2014): 448-454. 
2. Heisler, Martin O., and Zig Lay ton-Henry. "Migration and the links between social and societal security." Identity, migration and the new security agenda in Europe (1993):

St. Martin's Press New York 148-66.: Cooper. Betsv C. "Refugees and National Securitv: Crossing the Threshold of Insecurity." Refugees Worldwide: Mental health 3 (2012): 173;

3. UNHCR, No Lost Generation:Protecting the futures of children affected by the crisis in Syria, Strategic Overview (2014)

4. Çelik Dirsehan, Meltem. 2014. "Paradigma Değişmesi Olarak Yeniden Doğan Pazarlar: Ortadoğu'da Değişimin Toplumsal Göstergeleri” (ed. M. S. Köktürk and oth.) Yeniden Doğan Pazarlar. Beta: İstanbul, Pp.49-88.

5. Castles, Stephen, et al. "Irregular Migration: Causes, Patterns, and Strategies."Global Perspectives on Migration and Development. Springer Netherlands, 2012. 117-151.

6. Edwards, Alice. "Temporary protection, derogation and the 1951 Refugee Convention." Melb. J. Int'l L. 13 (2012): 595.; Http://Www.Uscis.Gov/Humanitarian/Temporary-Protected-Status

7. United Nations High Commissioner for Refugees official data: Http://Data.Unhcr.Org/Sy rianrefugees/Country.P (last updated:03.11.2015)

8. World Bank official data: http://data.worldbank.org/indicator/NY.GDP.PCAP.CD/countries/TR-7E?display=graph

9. Http://Www.Ny times.Com/2014/02/16/Magazine/How-To-Build-A-Perfect-RefugeeCamp.Html?_R=0 36 Blurring The Borders: Syrian Spillover Risks For Turkey, International Crisis Group, No: 225, 30 Nisan 2013, S.8,

10. AFAD official data: https://www.afad.gov.tr/TR/IcerikDetay 1 .aspx?ID=16\&IcerikID=848 (last updated:23.11.2015)

11. Memis. Hasan. "Ic Savas Nedenivle Kilis’te Yasavan Surivelilerin Olusturduğu SosvoEkonomik Algilar Üzerine Bir Araștirma." Elektronik Sosyal Bilimler Dergisi 14.52 (2015).

12. Barthes, Roland. "The photographic message." Theorizing communication: readings across traditions (2000): 191-199.; Kuhn, Annette. The power of the image: Essays on representation and sexualitv. Routledge. 2013.: Wright. Terence. "Moving images: The media representation of refugees."Visual Studies 17.1 (2002): 53-66.

13. Paul, Diane. "A time to act: The argument for no-fly zones and safe areas to protect civilians in Syria." (2013).; Josh Rogin, Putin Has His Own No-Fly Zone in Syria, Oct 2, 2015.

14. Erdoğan, M. Murat. "Perceptions of Syrians in Turkey." Turkey's Guests Refugees And Migrants (2014): 65.: Kirisci. Kemal. Svrian Refugees and Turkev's Challenges: Going Bey ond Hospitality. Washington, DC: Brookings Institution.(2014).

15. Alsaud, Fahdah Fahd. "Children's Rights: Syrian Refugee Camps... Childhood Underfire." J. Pol. \& L. 8 (2015): 228.

16. Dincer, Osman Bahadır, et al. Turkey and Sy rian Refugees: The Limits of Hospitality . International Strategic Research Organization (USAK), 2013.

17. Zencir, M., Davas, A. Suriy eli Sığınmacılar ve Sağlık Hizmetleri Raporu, Ankara Türk Tabipleri Birliği Yayınları,( 2014)

18. Park, Jumin. "The Self-Esteem and Depressive Symptom of Young North Korean Refugees (NKRs) Living in South Korea: Comparative Study." 43rd Biennial Convention (07 November-11 November 2015). STTI. 2015

19. Scheel, Stephan, and Philipp Ratfisch. "Refugee Protection Meets Migration Management: UNHCR as a Global Police of Populations." Journal of Ethnic and Migration Studies 40.6 (2014): 924-941.; Sanyal, Romola. "Refugees and the city: an urban discussion." Geography Compass 6.11 (2012): 633-644.

20. Campbell. Charlie Scapegoat: A Historv of Blaming Other People. Duckworth other: London, (2011). ; DeSantis, Ly dia. "Building healthy communities with immigrants and refugees."Journal of Transcultural Nursing 9.1 (1997): 20-31.; Uehling, Greta. "Children's Migration and the Politics of Compassion."Anthropology News 49.5 (2008): 8-10.; Heathcott, Joseph. "Moral panic in a plural culture." CrossCurrents 61.1 (2011): 39-44.

21. Goffman, E. Stigma: Notes on the Management of Spoiled Identitv. Touchstone Book: New York, 1986.; Becker, Howard S. "Definitions of deviance." Understanding Deviance: Connecting Classical and Contemporary Perspectives (2014): 18

22. Phillimore, Jenny, and Lisa Goodson. "Problem or opportunity? Asylum seekers, refugees, employment and social exclusion in deprived urban areas."Urban Studies 43.10 (2006): 1715 1736. 